\title{
PLA FILMS LOADED WITH Achillea millefolium - IN VITRO ANTIBACTERIAL EFFECTS
}

\author{
Aleksandra R. Novaković ${ }^{*}$, Tanja I. Radusin, Alena M. Tomšik, Predrag M. Ikonić \\ University of Novi Sad, Institute of Food Technology, 21000 Novi Sad, Bulevar cara Lazara 1, Serbia
}

*Corresponding author:
Phone: +381214853770
Fax: +38121450725
E-mail address: aleksandra.novakovic@fins.uns.ac.rs

\begin{abstract}
Antimicrobial packaging as active food packaging represents a suitable packaging form for food in products in particular for foods where microbial contamination occurs primarily at the surface. Poly (lactic acid) (PLA) is one of the most frequently used bio-polymers because of its similarities to conventional polymeric materials used in food packaging, however its use is still limited to short-term packaging applications. This research has been focused on preparation of PLA packaging films modified with bioactive compounds from Achillea millefolium (AM) plant extract as possible active packaging solution. Addition of specific natural compounds could give improvements in mechanical, thermal or barrier properties, as well as the antimicrobial effect with significant impact on prolonging the food shelf-life and its quality and safety.

Accordingly, the aim of this study was to determine chemical and antimicrobial properties of crude AM ethanolic extract and PLA composite films loaded with two concentrations of AM extract expressed in weight percent ( $2 \mathrm{wt}$. \% and $5 \mathrm{wt}$. \%). The AM ethanolic extract showed very good antimicrobial activity against $E$. coli and S. aureus, while PLA films loaded with $5 \%$ AM extract showed significant reduction of initial $S$. aureus after $24 \mathrm{~h}$ contact time compared to neat PLA films (up to 90\%). PLA films with $2 \%$ and $5 \%$ AM content did not show any antimicrobial activity against $E$. coli. Furthermore, the chemical composition of the ethanolic extract was determined considering its phenolic composition. These results indicated promising potential of incorporation of $A$. millefolium extract in PLA as an antimicrobial agent for food packaging applications.
\end{abstract}

Key words: antimicrobial packaging, antimicrobial activity, surface contamination, bioactive compounds, Escherichia coli, Staphylococcus aureus

\section{INTRODUCTION}

Food packaging is designed to protect food from environmental influences such as temperature, light and humidity, odors, microorganisms and dust that can lead to their degradation (Ribeiro-Santos et al., 2017). Commonly, microbial contamination is the main reason for food spoilage, therefore numerous food products require protection against microbial spoilage and lipid oxidation during their shelflife. The growing demand of consumers for safe and natural products, without chemical additives, has resulted in many researches with the aim to improve the quality and safety of products, while maintaining their good nutritional and organoleptic properties and, mainly, controlling foodborne pathogens (Carocho et al., 2015). Aiming to the reduction of the use of chemical additives in food industry, growing interest has been raised recently on the use of natural food additives with 
antimicrobial and antioxidant properties that do not have any negative effects on the human health (Atares and Chiralt, 2016). Therefore, food industry was forced to develop new ways and technologies to satisfy the consumers' demands. In line with this, active packaging has emerged (Ribeiro-Santos et al., 2017). Innovations in food packaging include the development of active packaging solutions based on the natural active compounds aimed at increasing both the shelf-life of packed food and the sustainability of the overall product (Radusin et al., 2018).

Antimicrobial packaging presents part of active packaging concept where the antimicrobial agent is incorporated into polymer film to suppress the activities of targeted microorganisms. Depending of the active molecule and the kind of package, the bioactive compounds can be released directly to the food surface or indirectly to the package headspace. Numerous researchers have demonstrated that direct application of antimicrobial agents in foods has limited benefits (Han et al., 2014; Kashiri et al., 2017).

However, antimicrobial packaging is still an extremely challenging technology as there are only a few commercialized products found on the market (Sung et al., 2013). Bioactive plants' extracts have gained scientific and industrial attention worldwide for their application as additives in many commercial preparations, mostly in the food and pharmaceutical sectors. For the creation of antimicrobial films it is also of great importance the choice of polymer matrix that will be used for food packaging. In the recent years biopolymers have been widely used, especially polylactides (PLA). PLA represent aliphatic polyester produced from renewable resources and while it has properties similar to the conventional polymers, it is very suitable as a food packaging material (John and Thomas 2008).

According to our knowledge, no work has been reported until now in the scientific literature on the use of Achillea millefolium (AM) extract for the development of active antimicrobial composite films for food packaging application. Therefore, the aim of this work was to develop an active composite material, based on a biopolymer (PLA) and bioactive natural compound (AM) extract, in specific.

For this purpose, PLA films with addition of two border concentrations of AM extract (2 and 5 wt. \%) were prepared and characterized in order to understand the influence of the extract addition on PLA films properties, as well as its potential for antimicrobial packaging application. This preliminary research should point out potential substitution of synthetic additives as antimicrobial agents, possibly broadening the use of biopolymers from renewable sources as sustainable and ecofriendly solutions for food packaging application.

\section{MATERIAL AND METHODS}

\section{Standards and reagents}

Methanol (HPLC, grade), quercetin and formic acid (HPLC grade) were supplied by Merck KGaA (Darmstadt, Germany). Standard substances including protocatechuic acid, caffeic acid, chlorogenic acid, rutin, rosmarinic acid, were purchased from Sigma-Aldrich $\mathrm{GmbH}$ (Sternheim, Germany). Water used throughout the experiments was purified using a MiIlipore, Elix UV and Simplicity Water Purification System (Milford, MA, USA)

\section{Samples}

Achillea millefolium was collected during the flowering period and the vegetative phase (July 2016) in Pale area, Bosnia and Herzegovina. The specimen was air dried mixed to obtain a homogenous sample and kept at $+4{ }^{\circ} \mathrm{C}$ until further analysis.

\section{Preparation of the extract}

Before extraction, the plant material was grounded in a blender. Crude plant extracts were obtained by maceration using ethanol/water mixture $(80: 20, \mathrm{v} / \mathrm{v})$, with the ratio of raw materials to ethanol solution of $1: 10$, for $24 \mathrm{~h}$ at room temperature and subsequently extracted in an ultrasonic bath at room temperature for $10 \mathrm{~min}$. The obtained extracts were filtered through the filter paper (Whatman No. 4). The solvent $(\mathrm{EtOH})$ was removed by rotary evaporator 
at $40{ }^{\circ} \mathrm{C}$ (Büchi, Switzerland). The obtained extract was stored at $+4{ }^{\circ} \mathrm{C}$. The relevant dried residues were redissolved in $\mathrm{EtOH}$ prior to analysis.

\section{Preparation of PLA film}

Semi-crystalline PLA was provided from Shenzhen Esun Industrial Co., Ltd (Shenzhen, China), characterized by a number-average molecular weight $M_{n}=$ $60520 \mathrm{~g} \mathrm{~mol}^{-1}$, weight-average molecular weight $\mathrm{M}_{\mathrm{w}}=160780 \mathrm{~g} \mathrm{~mol}^{-1}$, and polydispersity index $(\mathrm{PDI})=2.66$. Pure PLA film and PLA films with 2 and 5 wt $\%$ of AM extract were prepared by solution casting method. Appropriate amounts of AM extract were added in chloroform and stirred in an ultrasonic bath for $10 \mathrm{~min}$. PLA was added to extract dispersion and stirring continued with magnetic bar for $4 \mathrm{~h}$ at room temperature. After complete PLA dissolution, samples were poured into glass Petri dishes $(10-\mathrm{cm}$ diameter) and vacuum dried at room temperature.

\section{Preparation of bacterial suspensions}

Antimicrobial properties were tested against two bacterial microorganisms: one Gram negative (G-) strain, Escherichia coli ATCC11105, and one Gram positive (G+) strain Staphylococcus aureus ATCC $6538 p$. Pure bacterial strains were subcultured on nutrient agar slants at $37^{\circ} \mathrm{C}$ for $18 \mathrm{~h}$. Thus, obtained culture was centrifuged at $7000 \mathrm{rpm}$ for $10 \mathrm{~min}$, the pellet was washed in sterile phosphate buffer solution (PBS) and suspended in saline solution in order to obtain a cell suspension of $10^{8} \mathrm{CFU} / \mathrm{mL}$.

\section{Antimicrobial activity extracts}

For further procedures, 96-well microplates were used to each well and $100 \mu \mathrm{l}$ of extract (10 wt. \% extract), $100 \mu \mathrm{l}$ of nutrient broth, and $50 \mu \mathrm{l}$ of bacterial suspensions were added and incubated at $37{ }^{\circ} \mathrm{C}$ for $24 \mathrm{~h}$. In order to count viable bacterial cells, $1.8 \mathrm{ml}$ of PBS was added to the tube, thus obtaining a $10-{ }^{1}$ dilution, which was then serially diluted and $0.1 \mathrm{ml}$ plated on Plate Count Agar (PCA). After incubation of the plates at $37^{\circ} \mathrm{C}$ for $24 \mathrm{~h}$, the number of colonies, corresponding to the number of viable cells, was counted as $\mathrm{CFU} / \mathrm{ml}$. The percentage of reduction of viable cells was determined, after averaging the triplicate counts, through the equation:

$\%$ reduction $=(a-b) \times 100 / a$

where $a-$ is the number of viable cells in the control (non- treated cells), and b - is the number of viable cells in the specimens containing $10 \%$ extract.

\section{Antimicrobial activity film}

The antimicrobial activity of PLA films (neat, with 2 wt. \% and 5 wt. \% of AM extract) against $E$. coli and $S$. aureus was tested according to the Japanese Industrial Standard JIS, Z. 2801:2000 (2000). Microorganism suspension containing about $5 \times 10^{5} \mathrm{CFU} / \mathrm{ml}$ was applied onto the active multilayers of $3 \times 3 \mathrm{~cm}$ area and covered by an inert piece of LDPE of $2.5 \times 2.5 \mathrm{~cm}$ and $90 \mathrm{~mm}$ of thickness. After incubation at room temperature and $95 \%$ R.H. for $24 \mathrm{~h}$, bacteria were recovered with PBS, and the viable cells determined by the conventional plate count method. This method is designed to evaluate the efficiency against bacteria on the surface of finished polymer products, including films and pieces. Pure PLA films were used as negative controls, whereas the tested bacterial inoculum without PLA films was used a positive control. All samples were analyzed in triplicate. The antibacterial activity was taken as the test surface reduction (R) using the expression:

$R=[\log (B / A)-\log (C / A)]$

where $A$ - is the mean of bacterial counts of the control sample immediately after inoculation, $B$ is the mean of bacterial counts of the control sample after $24 \mathrm{~h}$, and $C$ is the mean of bacterial counts of the test sample after $24 \mathrm{~h}$. Antimicrobial activity was evaluated with the following assessment according to manufacturer procedure: no significant $(R<0.5)$, slight $(R \geq 0.5$ and $<1)$, significant $(R \geq 1$ and $<$ $3)$, and strong $(R \geq 3)$.

\section{Phenolic compounds composition}

Phenolic compounds were determined by HPLC (Agilent 1200 series), equipped with a diode array detector (DAD), Chemstation Software (Agilent Technologies) as 
previously described by the authors (Mišan et. al., 2011). The phenolic compounds were characterized according to their UV and mass spectra and retention times, and comparison with authentic standards when available. For quantitative analysis, calibration curves were prepared from different standard compounds. The results were expressed in $\mathrm{mg} / \mathrm{g}$ of dry weight (d.w.) extract.

\section{RESULTS AND DISCUSSION}

\section{Antimicrobial properties}

The present study has revealed the antibacterial activity $A$. millefolium extracts against G- E. coli and $G+S$. aureus bacteria (Figure 1,2). The percentage of reduced viable cells for each bacterium was calculated referring to the control, that is, a bacterial suspension without antimicrobial agent. According to the presented results, AM extracts $(1.5 \%, 2 \%)$ were effective against $E$. coli and $S$. aureus, showing $100 \%$ reduction of viable cells compared to control.

According to Stojanović et al. (2005) antibacterial activity of the examined extracts (hexane: ether: methanol $=1: 1: 1$ ) of the aerial parts of Achillea species: $A$. clavennae, $A$. holosericea Sm., A. lingulata and $A$. millefolium showed to possess a broad spectrum of antimicrobial activity against five bacteria ( $S$. aureus, E. coli, K. pneumoniae, $P$. aeruginosa and Salmonella enteritidis) and two fungi (Aspergillus niger and Candida albicans). Conversely, in another study, the ethanol extract of Turkish $A$. millefolium did not show any antibacterial activity (Unal et al., 2008). These differences may be attributed to the genotypic variation and/or climatic conditions.

Antimicrobial properties of PLA loaded with 2 and 5 wt. \% AM extract against $S$. aureus are shown in Figure 3. According to the presented results both polymer composites loaded with 2 and 5 wt. \% AM extract showed antimicrobial activity against $S$. aureus. PLA films loaded with 2 wt. \% AM extract resulted with test surface reduction value, $\mathrm{R}=0.92$, which indicates slight antimicrobial activity. While the samples loaded with 5 wt. \% AM extract showed significant $(R \geq 1$ and $<3$ ) antimicrobial activity $(R=1.9)$. However, the PLA films loaded with 2 and 5 wt\% AM extract did not show significant $(R<0.5)$ antimicrobial activity against $E$. coli. In general, analysis showed that PLA films with $A M$ extract was inactive against $E$. coli.

These results are in accordance with previous studies where ethanolic extract A. millefolium from Siberia and the Brazil was examinated (Kokoska et al., 2002; Holetz et al., 2002). This and many previous studies (Smith-Palmer et al., 1998; Lopez et al., 2005; Shan et al., 2007) indicated that AM extract was more active against $G$ + bacteria than $G$ - bacteria. This is likely due to the significant differences in the outer layers of G- and G+. G- possesses an outer membrane and a unique periplasmic space unlike in $G+$ bacteria (Nikaido 1996; Duffy and Power 2001).

Additionally, the resistance of G - bacteria toward antibacterial substances is related to the hydrophilic surface of their outer membrane which is rich in lipopolysaccharide molecules, presenting a barrier to the penetration of numerous antibiotic molecules, and is also associated with the enzymes in the periplasmatic space, which are capable of breaking down the molecules introduced from outside (Nikaido 1994; Gao, et al., 1999). G + bacteria do not have such an outer membrane and cell-wall structure therefore antibacterial substances can easily destroy the bacterial cell-wall and cytoplasmic membrane and result in a leakage of the cytoplasm and its coagulation (Shan et al., 2007).

According to the obtained results it might be suggested that the antimicrobial activity of the AM extract is also dependent on the tested bacterial species and their difference in cell - wall structure. Additionally, antimicrobial activity of extract depends on part of the plant used for extraction, the type of solvent, the extraction method, as well as the strain of microorganism examined (Lupoae et al., 2015). However, the effects observed for sample also strongly depend on the specific mixture of compounds present in the sample, 
their interaction and action of their metabolites that induce specific and often unexpected cellular responses.

Chemical composition regarding bioactive compounds

The chemical composition of $A$. millefolium regarding the bioactive folium compounds of its ethanolic extract is presented in Table 1.

Phenolic compounds are particularly potent natural products with a wide range of biological activities (Bais et al., 2002; Rahman and Moon 2007; Ayaz et al., 2008).

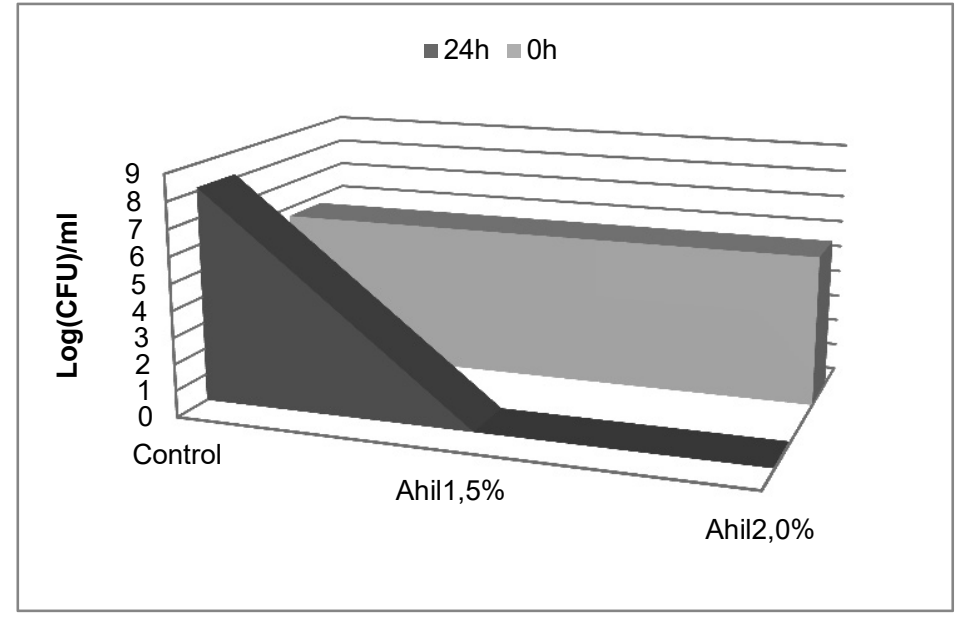

Figure 1. Antibacterial activity of AM extract against $E$. coli

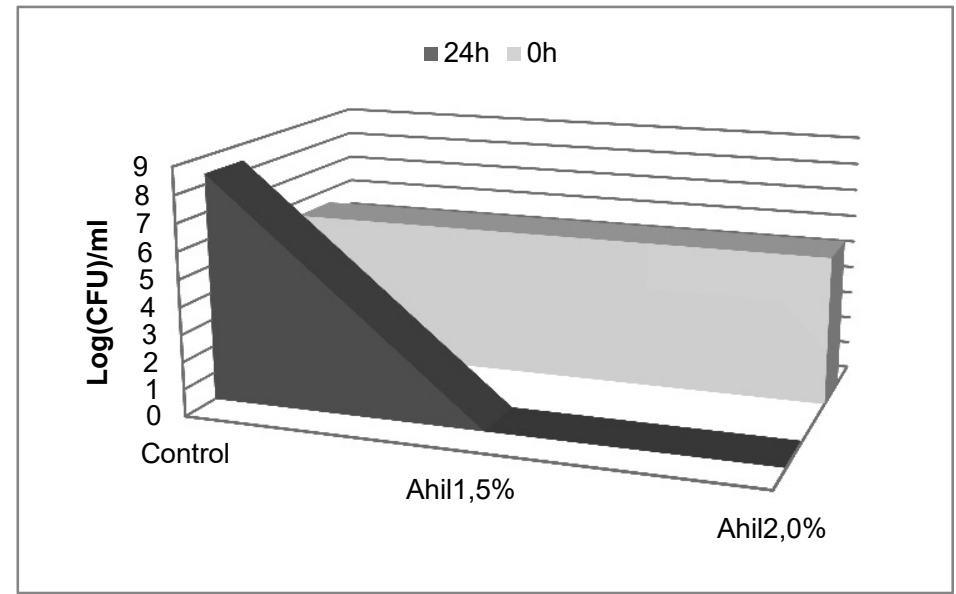

Figure 2. Antibacterial activity AM of extract against $S$. aureus

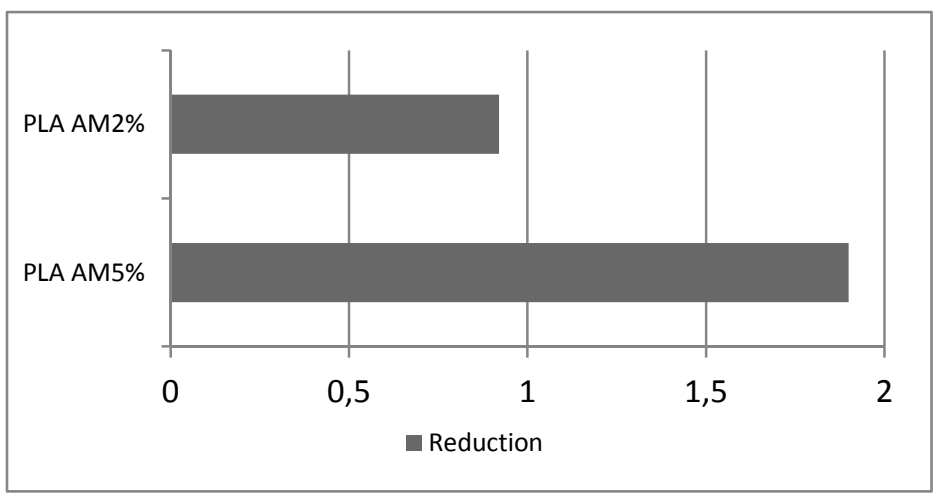

Figure 3. Antibacterial activity of PLA loaded with AM extract against S. aureus 
Table 1.

Content of phenolic compounds in crude AM ethanolic extracts

\begin{tabular}{cc}
\hline Phenolic compounds & $\begin{array}{c}\text { Content } \\
\mathrm{mg} / \mathrm{g}\end{array}$ \\
\hline Caffeic acid & 11.2480 \\
Rosmarinic acid & 2.3067 \\
Protocatechuic acid & 0.0597 \\
Chlorogenic acid & 0.0764 \\
Rutin & 6.9223 \\
Catechin & 0.8892 \\
\hline
\end{tabular}

The antimicrobial activity of phenolic acids is well documented in the literature (Heleno et al., 2013). Extracts of various medicinal plants (Cowan, 1999; Rios and Recio, 2005) containing phenolics including flavonoids have been previously reported to possess antimicrobial activity.

For instance, chlorogenic acid and catechin, detected also in examined AM extract, are known to exhibits a great inhibitory effect on E. coli and Listeria innocua (Muthuswamy and Rupasinghe, 2007) In the examined extract of AM, caffeic acid was detected as dominant and the most abundant compound. This acid is one of the most popular food additive regarding requirements of thermal processing reduction of heat sensitive foods (Bowles and Miller 1994). In addition, rosmarinic acid, protocatechuic acid and rutin were identified. According to the chemical profile of phenolic compounds in examined AM extract, the observed antimicrobial activities of AM extract and PLA loaded with AM extract might be due to the presence of phenolic compounds.

\section{CONCLUSIONS}

Crude extract of $A$. millefolium possessed high antimicrobial properties against $E$. coli and S. aureus. Films loaded with $2 \mathrm{wt}$. $\%$ AM extract showed slight antimicrobial activity; while PLA film loaded with 5 wt. \% AM extract showed significant antimicrobial activity against $S$. aureus. Antimicrobial activity of both samples is related to AM content into PLA polymer matrix compared with neat PLA, pointing out the clear antimicrobial activity of the AM extract.

Antimicrobial activities observed in this study might be due to the presence of phenolic compounds. This research presents a preliminary study on AM extract as suitable natural additive for improvement of PLA material properties as well as potential antimicrobial compound for use in prepared composite as active packaging solution.

\section{ACKNOWLEDGMENTS}

Provincial Secretariat for Higher Education and Scientific Research, Republic of Serbia contract grant number: 142-4512771/2017-01-01

\section{REFERENCES}

1. Atarés, L., Chiralt, A. (2016). Essential oils as additives in biodegradable films and coatings for active food packaging. Trends in Food Science and Technology, 48, 51-62.

2. Ayaz, F.A., Hayırlıglu-Ayaz, S., AlpayKaraoglu, S., Grúz, J., Valentová, K., Ulrichová, J., Strnad, M. (2008). Phenolic acid contents of kale (Brassica oleraceae L. var. acephala DC.) extracts and their antioxidant and antibacterial activities. Food Chemistry, 107 (1), 19-25.

3. Bais, H.P., Walker, T.S., Schweizer, H.P. and Vivanco, J.M. (2002). Root specific elicitation and antimicrobial activity of rosmarinic acid in hairy root cultures of Ocimum basilicum. Plant Physiology and Biochemistry, 40 (11), 983-995.

4. Bowles, B.L., Miller, A.J. (1994). Caffeic acid activity against Clostridium botulinum spores. Journal of Food Science, 59 (4), 905-908.

5. Carocho, M., Morales, P., Ferreira, I.C. (2015). Natural food additives: Quo vadis? Trends in Food Science and Technology, 45 (2), 284295.

6. Duffy, C.F., Power, R.F. (2001). Antioxidant and antimicrobial properties of some Chinese plant extracts. International Journal of Antimicrobial Agents, 17 (6), 527-529.

7. Gao, Y., van Belkum, M.J., Stiles, M.E. (1999). The outer membrane of Gram-negative bacteria inhibits antibacterial activity of brochocin-C. Applied and Environmental Microbiology, 65 (10), 4329-4333. 
8. Han, C., Wang, J., Li, Y., Lu, F., Cui, Y. (2014). Antimicrobial-coated polypropylene films with polyvinyl alcohol in packaging of fresh beef. Meat Science, 96 (2), 901-907.

9. Heleno, S.A., Ferreira, I.C., Esteves, A.P., Ćirić, A., Glamočlija, J., Martins, A., Soković, M., Queiroz, M.J.R. (2013). Antimicrobial and demelanizing activity of Ganoderma lucidum extract, p-hydroxybenzoic and cinnamic acids and their synthetic acetylated glucuronide methyl esters. Food and Chemical Toxicology, 58, 95-100.

10. JISZ 2801:2000 (2000). Antimicrobial productsTests for antimicrobial activity. Japanese Industrial Standards Committee, Tokyo, Japan (http://www.jisc.go.jp/eng/).

11. Kashiri, M., Cerisuelo, J.P., Domínguez, I., López-Carballo, G., Muriel-Gallet, V., Gavara, R., Hernández-Muñoz, P. (2017). Zein films and coatings as carriers and release systems of Zataria multiflora Boiss. essential oil for antimicrobial food packaging. Food Hydrocolloids, 70, 260-268.

12. Lopez, P., Sanchez, C., Batlle, R., Nerin, C. (2005). Solid-and vapor-phase antimicrobial activities of six essential oils: susceptibility of selected foodborne bacterial and fungal strains. Journal of Agricultural and Food Chemistry, 53 (17), 6939-6946.

13. Mišan, A., Mimica-Dukić, N., Mandić, A., Sakač, M., Milovanović, I., Sedej, I. (2011). Development of a rapid resolution HPLC method for the separation and determination of 17 phenolic compounds in crude plant extracts. Open Chemistry, 9 (1), 133-142.

14. Muthuswamy, S., Rupasinghe, H.V. (2007). Fruit phenolics as natural antimicrobial agents: Selective antimicrobial activity of catechin, chlorogenic acid and phloridzin. Journal of Food Agriculture and Environment, 5 (3/4), 81.

15. Nikaido, H. (1996). Multidrug efflux pumps of gram-negative bacteria. Journal of Bacteriology, 178 (20), 5853.
16. Nikaido, H. (1994). Prevention of drug access to bacterial targets: permeability barriers and active efflux. Science, 264 (5157), 382-388.

17. Rahman, M.A.A., Moon, S.S. (2007). Antimicrobial phenolic derivatives from Dendranthema zawadskii var. latilobum kitamura (Asteraceae). Archives of Pharmacal Research, 30 (11), 1374-1379.

18. Ribeiro-Santos, R., Andrade, M., de Melo, N.R., Sanches-Silva, A. (2017). Use of essential oils in active food packaging: Recent advances and future trends. Trends in Food Science and Technology, 61, 132-140.

19. Shan, B., Cai, Y.Z., Brooks, J.D., Corke, H. (2007). Antibacterial properties and major bioactive components of cinnamon stick (Cinnamomum burmannii): activity against foodborne pathogenic bacteria. Journal of Agricultural and Food Chemistry, 55 (14), 54845490.

20. Smith-Palmer, A., Stewart, J., Fyfe, L. (1998). Antimicrobial properties of plant essential oils and essences against five important food-borne pathogens. Letters in Applied Microbiology, 26 (2), 118-122.

21. Sung, S.Y., Sin, L.T., Tee, T.T., Bee, S.T., Rahmat, A.R., Rahman, W.A. W.A., Tan, A.C. Vikhraman, M. (2013). Antimicrobial agents for food packaging applications. Trends in Food Science and Technology, 33 (2), 110-123.

22. Cowan, M.M. (1999). Plant products as antimicrobial agents. Clinical Microbiology Reviews, 12 (4), 564-582.

23. Rios, J.L., Recio, M.C. (2005). Medicinal plants and antimicrobial activity. Journal of Ethnopharmacology, 100 (1-2), 80-84.

24. Unal, E.L., Mavi, A., Kara, A.A., Cakir, A., Şengül, M., Yildirim, A. (2008). Antimicrobial and antioxidant activities of some plants used as remedies in Turkish traditional medicine. Pharmaceutical Biology, 46 (3), 207-224. 


\title{
ПЛА ФИЛМОВИ СА ДОДАТКОМ Асhillea millefolium - IN VITRO АНТИМИКРОБНИ ЕФЕКАТ
}

\author{
Александра Р. Новаковић*, Тања И. Радусин, Алена М. Томшик, Предраг М. Иконић \\ Универзитет у Новом Саду, Научни институт за прехрамбене технологије у Новом Саду, \\ 21000 Нови Сад, Булевар цара Лазара 1, Србија
}

Сажетак: Антимикробно паковање као врста активног паковања, представља одговарајућу амбалажу за паковање прехрамбених производа, посебно за храну која је склона микробиолошкој контаминацији. Полимлечна киселина (ПЛА) је један од најчешће заступљених полимера због њене сличности са кновненционалним полимерним материјалима који се користе као амбалажни материјал. Међутим примена ПЛА још увек није довољно развијена. Ово истраживање је фокусирано на примени ПЛА филмова за паковање који су модификовани додатком биактивних компоненти из екстракта Achillea millefolium у циљу добијања нових активних амбалажних филмова. Додатком одређених једињења природног порекла може доћи до побољшања механичких, термалних и/или баријерних особина, као и до антимикробног деловања, што значајно продужава рок трајања и чува квалитет и безбедност упакованог производа.

Циљ овог истраживања био је да се утврде хемијска и антимикробна својства сирових AM етанолних екстраката и ПЛА филмова са додатком две концентрације АМ екстракта (2\% и $5 \%$ ). Етанолни екстракт AM показао је веома добру антимикробну активност против E. coli и $S$. aureus, док је ПЛА са 5\% екстракта показао значајну антимикробну активност против $S$. aureus након 24 сата контактног времена у поређењу са контролним узорком ПЛА (до 90\%). ПЛА филмови са садржајем 2\% AM и 5\% AM нису показали антимикробну активност против E. coli. Поред тога, хемијски састав етанолног екстракта одређен је с обзиром на његов фенолни састав. Ови резултати показују обећавајући потенцијал укључивања екстракта Achillea millefolium у ПЛА као антимикробног агенса за паковање хране.

Кључне речи: полимлечна киселина (ПЛА), Achillea millefolium, антимикробно паковање, антимикробна активност

Received: 16 May 2018

Received in revised form: 31 May 2018

Accepted: 7 June 2018 